\title{
Phylogeny of the lamprey genus Lampetra inferred from mitochondrial cytochrome b and ND3 gene sequences
}

\author{
Margaret F. Docker, J ohn H. Youson, Richard J . Beamish, and \\ Robert H. Devlin
}

\begin{abstract}
Mitochrondrial DNA analysis resolved many previously unanswered questions concerning the phylogeny of the lamprey genus Lampetra (comprising the subgenera Entosphenus, Lethenteron, and Lampetra). A total of 735 base pairs were sequenced from the cytochrome $b$ and NADH dehydrogenase subunit 3 (ND3) genes in 11 lamprey species. With the exception of $L$. (E.) hubbsi from California, species of the Entosphenus subgenus formed a tight-knit clade that was very distinct from the other two subgenera. Lampetra hubbsi clustered with species of the Lampetra subgenus from the west coast of North America (L. ayresii and L. richardsoni) whereas species of the Lampetra subgenus from Atlantic drainages, namely the North American L. aepyptera and European L. fluviatilis, formed a third cluster. A fourth cluster included two species from the Lethenteron subgenus (L. japonica and L. appendix). Inclusion of published data from a third Lethenteron species, L. zanandreai, showed it to group with the $L$. (L.) fluviatilis lineage rather than with the other two Lethenteron species. Within each subgenus, members of paired and satellite species were closely related to one another (e.g., L. japonica and L. appendix) or were genetically indistinguishable (e.g., L. ayresii and $L$. richardsoni). Using rates of molecular evolution estimated in other fish taxa, these genetically indistinguishable species diverged less than 70000 years ago.
\end{abstract}

\begin{abstract}
Résumé : L'analyse de l'ADN mitochrondial a permis de répondre à bon nombre de questions relativement à la phylogénie du genre de lamproie Lampetra (englobant les sous-genres Entosphenus, Lethenteron et Lampetra). On a déterminé la séquence d'un total de 735 paires de bases des gènes pour la cytochrome $b$ et la sous-unité 3 de la NADH déshydrogénase (ND3) chez 11 espèces de lamproie. À l'exception de L. (E. ) hubbsi de la Californie, les espèces du sous-genre Enthosphenus formaient un clade cohérent très distinct de ceux des deux autres sous-genres. Lampetra hubbsi se rapprochait des espèces du sous-genre Lampetra de la côte ouest de l'Amérique du Nord (L. ayresii et $L$. richardsoni) tandis que les espèces du sous-genre Lampetra des bassins de l'Atlantique, à savoir $L$. aepyptera de l'Amérique du Nord et $L$. fluviatilis de l'Europe formaient un troisième groupe. Un quatrième groupe englobait deux espèces du sous-genre Lethenteron ( $L$. japonica et L. appendix). L'ajout de données publiées pour une troisième espèce de Lethenteron, L. zanandreai, indiquait une parenté avec $L$. (L.) fluviatilis plutôt qu'avec les deux autres espèces de Lethenteron. Au sein de chaque sous-genre, les membres d'espèces appariées et satellites étaient fortement apparentés les uns aux autres (p. ex. L. japonica et $L$. appendix) ou étaient génétiquement indiscernables (p. ex. L. ayresii et L. richardsoni). L'utilisation des taux d'évolution moléculaire estimés pour d'autres taxons de poisson montre que ces espèces génétiquement indiscernables ont divergé il y a moins de 70000 ans.
\end{abstract}

[Traduit par la Rédaction]

\section{Introduction}

Lampreys are extant representatives of the ancient vertebrate group Agnatha and are one of the oldest groups of living fishes in the fossil record, about 300 million years old (Janvier and Lund 1983). There are about 40 extant species of lampreys; four species described from the Southern Hemisphere have been placed in the families Geotriidae and Mordaciidae, while the remaining species inhabit the Northern Hemisphere. The Northern Hemisphere lampreys belong to a single family, Petromyzonidae, and have been assigned to at least six genera (Hubbs and Potter 1971; Potter 1980).

Received January 7, 1999. Accepted August 6, 1999.

$\mathrm{J} 14968$

M.F. Docker ${ }^{1}$ and R.H. Devlin. Department of Fisheries and Oceans, West Vancouver Laboratory, 4160 Marine Dr., West Vancouver, BC V7V 1N6, Canada.

J.H. Youson. Division of Life Sciences, University of Toronto at Scarborough, 1265 Military Trail, Scarborough, ON M1C 1A4, Canada.

R.J. Beamish. Department of Fisheries and Oceans, Pacific Biological Station, Nanaimo, BC V9R 5K6, Canada.

${ }^{1}$ Author to whom all correspondence should be sent at the following address: Biology Program, College of Science and Management, University of Northern British Columbia, 3333 University Way, Prince George, BC V2N 4Z9, Canada.

e-mail: docker@unbc.ca 
Lamprey taxonomy is problematic because, compared with bony vertebrates, there are relatively few taxon-distinctive morphological characters. Species identification and generic status have been largely based on adult dentition, as well as on differences in body proportions, number of myomeres, number and morphology of velar tentacles, and pigmentation (Hubbs and Potter 1971; Richards et al. 1982).

Adult body size, life history type, and habitat are also commonly used to distinguish between closely related taxa. All lampreys spend the first years of life as blind larvae that burrow in the silt bottoms of rivers and streams and feed on microscopic organisms. Following metamorphosis, they may remain nontrophic (nonparasitic) in their natal stream and spawn and die within 6-9 months, or they may migrate to freshwater lakes or to seawater and become trophic (parasitic). In most lamprey genera, groups of two or more species exist in which the larvae are morphologically similar but the species adopt different life history types as adults. It is generally believed that these so-called "paired species" (Zanandrea 1959) or multiple "satellite species" (Vladykov and Kott 1979a) are very closely related, with the nonparasitic species having evolved from a parasitic ancestor (Zanandrea 1959). Not all authorities, however, recognize life history type as a reliable indication of species differentiation (e.g., McPhail and Lindsey 1970) and consider paired or satellite species to be races or types of a single species. An objective of the current study was to determine the degree of molecular divergence between paired or satellite species.

A second objective was to use molecular data to test the evolutionary relationships among some higher lamprey taxa. A specific goal was to resolve the relationships among the 15 or more species currently assigned to the genus Lampetra (Potter 1980), which has controversial morphological characters (Table 1). Potter (1980) named Entosphenus, Lethenteron, and Lampetra as subgenera within the genus Lampetra, whereas other authors (e.g., Vladykov and Kott 1979a) classified each as distinct genera and further recognized a division between the taxa by placing Entosphenus into a separate subfamily from Lampetra and Lethenteron. Taxonomic questions centre on the degenerate or intermediate characteristics of several so-called relict species, nonparasitic lampreys that occur at or near the extreme southern limits of distribution of the Northern Hemisphere lampreys (Hubbs and Potter 1971). One such relict species is Lampetra (Entosphenus) hubbsi from California (Vladykov and Kott 1976a), which appears to demonstrate an intergradation of characters among the three subgenera (Table 1). Similarly, two other nonparasitic species, Lampetra (Lampetra) aepyptera and Lampetra (Lethenteron) zanandreai, possess ambiguous morphological characters (Table 1). The current study examined the evolutionary relationships among the three subgenera of Lampetra and evaluated the relationships of the relict species $L$. hubbsi and L. aepyptera.

Given the inclusiveness and overlap of lamprey morphological characters, an independent molecular data set from mitochondrial DNA sequences is used to resolve these taxonomic issues. In this study, we sequenced the entire NADH dehydrogenase subunit 3 (ND3) gene and about one third of the cytochrome $b$ gene from 11 species of lampreys of the genus Lampetra and compared the data with published cytochrome $b$ sequences from two additional Lampetra spe- cies (Tagliavini et al. 1994). Cytochrome $b$ sequence has been used to resolve phylogenetic relationships in a variety of fish taxa (e.g., Cantatore et al. 1994), and the ND3 gene, which appears to evolve somewhat faster than cytochrome $b$ (Thomas and Beckenbach 1989; McVeigh and Davidson 1991), may be useful in distinguishing among some of the more closely related paired and satellite species.

\section{Materials and methods}

Eleven lamprey species of the genus Lampetra were collected in Canada (British Columbia and Ontario), the United States (Oregon, California, and Tennessee), Germany, and Russia (Table 2). Species identification was confirmed morphologically in adults; ammocoetes were used only where a single species was present or where adequate larval characteristics exist to distinguish between species (Richards et al. 1982). DNA analysis was performed on two to four individuals per species or collection site. A single landlocked sea lamprey (Petromyzon marinus) from Ontario was collected for use as an outgroup, and cytochrome $b$ and ND3 sequences were compared with those from an anadromous sea lamprey from New Hampshire (Lee and Kocher 1995). All samples were either frozen at $-70^{\circ} \mathrm{C}$ or preserved in $95 \%$ ethanol.

In $L$. japonica, DNA was extracted from liver tissue by digesting overnight at $37^{\circ} \mathrm{C}$ with proteinase $\mathrm{K}$ in proteinase $\mathrm{K}$ buffer $(10 \mathrm{mM}$ Tris $(\mathrm{pH} 8.0), 10 \mathrm{mM}$ EDTA, 1\% SDS, $200 \mu \mathrm{g}$ proteinase $\mathrm{K} / \mathrm{mL}$ ), cleaning with phenol-chloroform (1:1), and precipitating with $\mathrm{NaOAc}$ and isopropanol. In the other specimens, DNA was extracted from fin or tail clippings, which were digested for $1 \mathrm{~h}$ at $55^{\circ} \mathrm{C}$ with proteinase $\mathrm{K}$ and used as crude homogenates.

Polymerase chain reaction (PCR) amplification of 414 base pairs (bp) at the $5^{\prime}$ end of the cytochrome $b$ gene used primers located in the tRNA-Glu and cytochrome $b$ genes: GLUDG-L (5'TGACTTGAARAACCAYCGTTG-3') and CB2-H (5'-CCCTCAGAATGATATTTGTCCTCA-3'), respectively (Palumbi 1996). Since lampreys possess a large noncoding region between these two genes (Lee and Kocher 1995), the PCR product exceeded $1000 \mathrm{bp}$. Two internal primers (5'-CCATCCAACATCTCAGCWTGATGAAA-3' (L) from Palumbi (1996) and 5'-CAAGGCTAGTTCAGTRTTAGC-3' $(\mathrm{H})$ designed from conserved regions of lamprey sequence) were used to amplify subsections of this larger fragment. The entire $351 \mathrm{bp}$ of the lamprey ND3 gene were amplified with primers designed from conserved regions in the tRNA-Arg gene of other vertebrates (e.g., Thomas and Beckenbach 1989) and the tRNA-Gly gene of sea lamprey (Lee and Kocher 1995): 5'ATGCGGATCCTTTTGAGCCGAAATCA-3' and 5'-ACGTGAATTCTATAGTTGGGTTCCAACCA-3', respectively.

Each $50-\mu \mathrm{L}$ reaction contained standard PCR buffer $(10 \mathrm{mM}$ Tris ( $\mathrm{pH} \mathrm{8.3),} 50 \mathrm{mM} \mathrm{KCl}, 1.5 \mathrm{mM} \mathrm{MgCl}_{2}, 0.001 \%$ gelatin), $0.2 \mathrm{mM}$ dNTP, 50 pmol of each primer, and 1.25 units of Taq DNA polymerase (Gibco BRL, Burlington, Ont.). The reactions were run in a Perkin Elmer thermocycler (Perkin Elmer Cetus, Norwalk, Conn.) for 30 cycles consisting of denaturation at $94^{\circ} \mathrm{C}$ for $1 \mathrm{~min}$, primer annealing at $60^{\circ} \mathrm{C}$ for $1 \mathrm{~min}$, and extension at $72^{\circ} \mathrm{C}$ for $2 \mathrm{~min}$; the 30 cycles were preceded by an initial denaturation for $3 \mathrm{~min}$ at $94^{\circ} \mathrm{C}$ and followed by a final $10-\min 72^{\circ} \mathrm{C}$ extension. Negative controls, which used distilled water instead of template DNA, were included in each series of reactions to screen for possible contamination.

The PCR products were sequenced using the Cyclist DNA Sequencing Kit (Stratagene, La Jolla, Calif.) or the Sequenase PCR Product Sequencing Kit (United States Biochemical, Cleveland, Ohio); the manufacturer's instructions were followed. Given the heteroplasmic nature of the noncoding insert located at the $5^{\prime}$ end of cytochrome $b$ (M.F. Docker, J.H. Youson, R.J. Beamish, J.M.P. Joss, T.D. Kocher, and R.H. Devlin, unpublished data), all cytochrome $b$ sequencing was accomplished from the $3^{\prime}$ end of the 
Table 1. Summary of the taxonomy of the lamprey genus Lampetra.

\begin{tabular}{l}
\hline Species \\
\hline Subgenus Lampetra \\
ayresii \\
(river lamprey) \\
richardsoni (western \\
brook lamprey) \\
pacifica (Pacific brook \\
lamprey) \\
fluviatilis (European \\
river lamprey) \\
planeri (European brook \\
lamprey) \\
aepyptera (least brook \\
lamprey)
\end{tabular}

Subgenus Entosphenus

tridentata (Pacific lamprey)

macrostoma (lake lamprey)

similis (Klamath River lamprey)

lethophaga (Pit-Klamath brook lamprey)

folletti

Comments regarding classification

Considered by Vladykov and co-workers as distinct genus and included in subfamily Lampetrinae with genera Lethenteron and Eudontomyzon ${ }^{1}$

Initially considered synonymous with $L$. fluviatilis; described as distinct species (Vladykov and Follett 1958)

Derivative of L. ayresii (Vladykov and Follett 1965)

Described as second nonparasitic derivative of $L$. ayresii (Vladykov 1973); now considered by American Fisheries Society to be synonymous with L. richardsoni ${ }^{3}$

Derivative of L. fluviatilis

Occurs far from any parasitic Lampetra; perhaps derived from L. ayresii, ${ }^{1}$ from EudontomyzonTetrapleurodon type,$^{6}$ or L. japonica ${ }^{4,7}$; may bridge gap between Lampetra and Lethenteron 7

Generic status in subfamily Entosphenidae with genus Tetrapleurodon

Derivative of L. tridentata (Beamish 1982); recognized as distinct species by American Fisheries Society $^{3}$

Derivative of L. tridentata (Vladykov and Kott $1979 b$ ); once regarded as subspecies of tridentata,${ }^{9}$ now recognized as distinct ${ }^{3}$

Derivative of L. tridentata (Hubbs 1971)

Described as second nonparasitic derivative of $L$. tridentata (Vladykov and Kott 1976c); considered by American Fisheries Society as synonymous with lethophaga ${ }^{9}$
Relevant morphological characteristics ${ }^{a}$

Life history type and distribution

Supraoral (SO) lamina 2 cusps; 3 inner

laterals $^{b}$ with 2-3-2 cusps; infraoral (IO) lamina 7-8 cusps; posterial circumorals (posterials) absent ${ }^{2}$

Velar tentacles 4; larger eye, longer prebrancial, and shorter branchial region relative to $L$. fluviatilis Fewer myomeres and less well-developed
teeth than typical $L$. richardsoni

Parasitic, anadromous; Pacific coast of North America from Skeena River, B.C., to San

Francisco Bay, Calif.

Nonparasitic, freshwater; Pacific drainages from B.C. to Oreg.

Nonparasitic, freshwater; Columbia River basin, Oreg.; San Joachin - Sacramento River system, Calif.

Parasitic, anadromous; western European watersheds of the Atlantic, Baltic, and Mediterranean; some landlocked ${ }^{4}$

Nonparasitic, freshwater; similar distribution to fluviatilis but further inland in central and northern Europe ${ }^{5}$

Dentition extremely degenerate and variable; posterials absent; reduced number of myomeres $^{8}$

SO lamina 3 cusps; 4 inner laterals with 23-3-2 cusps; IO lamina with 5 cusps; posterials present ${ }^{2}$

Posterials 18 (2 bicuspid); velar tentacles 13

Posterials 18 (3 bicuspid); velar tentacles 13

Posterials 18 (6 bicuspid); velar tentacles 8

Dentition more variable and degenerate than other Entosphenus; velar tentacles 8; adult size about $140 \mathrm{~mm}^{10}$

Dentition more robust than typical

lethophaga; adult size about $200 \mathrm{~mm}$
Parasitic, anadromous; spawns in rivers of Pacific basin from Alaska to southern Calif. Parasitic, freshwater; reported only in 2 lakes on Vancouver Island, B.C.

Parasitic, freshwater; Klamath River drainage, Calif. and Oreg. Ohio River basin, Gulf and Atlantic plains

Nonparasitic, freshwater; Klamath and Pit River systems in Oreg. and Calif.

Nonparasitic, freshwater; restricted to Klamath River drainage of northern Calif. 
Table 1 (concluded).

\begin{tabular}{|c|c|c|c|}
\hline Species & Comments regarding classification & Relevant morphological characteristics ${ }^{a}$ & Life history type and distribution \\
\hline $\begin{array}{l}\text { hubbsi (Kern brook } \\
\text { lamprey) }\end{array}$ & $\begin{array}{l}\text { Presumed derivative of } L . \text { tridentata (Vladykov } \\
\text { and Kott } 1976 a \text { ), although prior to canal, Kern } \\
\text { River basin lacked connection with other } \\
\text { Entosphenus; } L .(\text { L.) pacifica (L. richardsoni) } \\
\text { only other species in canal }\end{array}$ & $\begin{array}{l}\text { SO lamina } 2 \text { cusps; } 4 \text { inner laterals } \\
\text { unicuspid; IO lamina } 5 \text { cusps; posterials } \\
\text { about } 10 \text { (unicuspid); velar tentacles } 3 ; \\
\text { reduced number of myomeres }\end{array}$ & $\begin{array}{l}\text { Nonparasitic, freshwater; limited distribution in } \\
\text { Calif. in San Joachin basin }{ }^{1} \text {; probably origi- } \\
\text { nated in Kern River, which now connects } \\
\text { with San Joachin River through artificial } \\
\text { Millerton Lake }\end{array}$ \\
\hline Subgenus Lethenteron & $\begin{array}{l}\text { Considered distinct genus in subfamily } \\
\text { Lampetrinae with Lampetra and } \\
\text { Eudontomyzon }{ }^{1}\end{array}$ & $\begin{array}{l}\text { SO lamina } 2 \text { cusps; } 3 \text { inner laterals with } 2- \\
2-2 \text { cusp pattern; IO lamina with }>5 \\
\text { cusps; unicuspid posterials }{ }^{6}\end{array}$ & \\
\hline $\begin{array}{l}\text { japonica (Arctic } \\
\text { lamprey) }\end{array}$ & & & $\begin{array}{l}\text { Parasitic, anadromous; from Varangar Fjord in } \\
\text { Europe to Pacific coast of Japan; in North } \\
\text { America, in Alaska and northern Canada }\end{array}$ \\
\hline $\begin{array}{l}\text { appendix (American } \\
\text { brook lamprey) }\end{array}$ & $\begin{array}{l}\text { Synonymous with } L . \text { (Le.) lamottenii; designated } L \text {. } \\
\text { appendix by American Fisheries Society }{ }^{9} \text {; current } \\
\text { distribution differs from } L \text {. japonica, but almost } \\
\text { certainly one of its many derivatives; considered } \\
\text { indistinguishable from } L .(\text { Le. }) \text { alaskense }{ }^{9}\end{array}$ & & $\begin{array}{l}\text { Nonparasitic, freshwater; tributarites of Great } \\
\text { Lakes, St. Lawrence and Mississippi River } \\
\text { systems, and rivers tributary to the Atlantic } \\
\text { from N.H. to N.C. }\end{array}$ \\
\hline $\begin{array}{l}\text { zanandreai (Po brook } \\
\text { lamprey) }\end{array}$ & $\begin{array}{l}\text { Originally Lampetra (Vladykov 1955), but } \\
\text { posterials and inner lateral cusp formula } \\
\text { suggest Lethenteron }{ }^{4} \text {; ancient southern relict of } \\
\text { L. (L.) fluviatilis }{ }^{1} \text { or } L .(\text { Le.) japonica }\end{array}$ & $\begin{array}{l}\text { Inner laterals } 2-2-2 \text { cusp pattern; single row } \\
\text { of minute posterials, which may sometimes } \\
\text { be lacking or deeply embedded }{ }^{11} \text {; velar } \\
\text { tentacles } 3-5 \text {; reduced number of myomeres }\end{array}$ & $\begin{array}{l}\text { Nonparasitic, freshwater; restricted to Po River } \\
\text { drainage in northern Italy }\end{array}$ \\
\hline
\end{tabular}

Note: References other than original species descriptions: 1, Vladykov and Kott (1979a); 2, Vladykov and Kott (1976a); 3, Robins et al. (1991); 4, Potter (1980); 5, Hardisty (1986); 6, Hubbs and Potter (1971); 7, Bailey (1980); 8, Vladykov and Kott (1976b); 9, Robins et al. (1980); 10, Vladykov and Kott (1976c); 11, Bianco (1986).

${ }^{a}$ Mean or mode given.

${ }^{b}$ Inner laterals equivalent to lateral circumorals. 
Table 2. Collection data for the lamprey species analyzed in this study.

\begin{tabular}{|c|c|c|c|}
\hline Species & Collection site & $N$ & Stage \\
\hline \multicolumn{4}{|l|}{ Genus Lampetra } \\
\hline \multicolumn{4}{|c|}{ Subgenus Lampetra } \\
\hline ayresii & Strait of Georgia, Fraser River discharge, B.C. & $2(\mathrm{fr})$ & Juvenile \\
\hline \multirow[t]{2}{*}{ richardsoni } & Cowichan River, Vancouver Island, B.C. & 2 (fr) & Ammocoete \\
\hline & Chemainus River, Vancouver Island, B.C. & $2(\mathrm{fr})$ & Ammocoete \\
\hline fluviatilis & Elba River, Germany & $2(\mathrm{EtOH})$ & Adult \\
\hline aepyptera & Cane Creek, Tenn. & $2(\mathrm{EtOH})$ & Ammocoete \\
\hline \multicolumn{4}{|c|}{ Subgenus Entosphenus } \\
\hline \multirow[t]{3}{*}{ tridentata } & Cowichan River, Vancouver Island, B.C. & $2(\mathrm{fr})$ & Ammocoete \\
\hline & Chemainus River, Vancouver Island, B.C. & $2(\mathrm{fr})$ & Ammocoete \\
\hline & Elk River, coastal Oreg. & $4(\mathrm{EtOH})$ & Ammocoete \\
\hline macrostoma & Cowichan Lake, Vancouver Island, B.C. & 2 (fr) & Juvenile \\
\hline \multirow[t]{2}{*}{ lethophaga } & Pit River, Calif. & 2 (fr) & Adult \\
\hline & Hat Creek, Calif. & 2 (fr) & Ammocoete \\
\hline similis $1-3$ & Agency Lake, Klamath Basin, Oreg. & 3 (fr) & Adult \\
\hline similis $4-7$ & Sprague River, Klamath Basin, Oreg. & 4 (fr) & Adult \\
\hline similis & Merced River, Calif. & $2(\mathrm{fr})$ & Ammocoete \\
\hline \multirow[t]{2}{*}{ hubbsi } & Merced River, Calif. & $2(\mathrm{fr})$ & Adult \\
\hline & Kings River, Calif. & $2(\mathrm{fr})$ & Adult \\
\hline \multicolumn{4}{|c|}{ Subgenus Lethenteron } \\
\hline japonica & Kamchatka Channel, Russia & $2(\mathrm{EtOH})$ & Adult \\
\hline appendix & Nolachucky River, Ont. & $2(\mathrm{EtOH})$ & Ammocoete \\
\hline \multicolumn{4}{|l|}{ Genus Petromyzon } \\
\hline marinus & Bronte Creek, Ont. (landlocked) & $1(\mathrm{EtOH})$ & Ammocoete \\
\hline
\end{tabular}

Note: Sample size $(N)$, method of preservation (fr, frozen at $-70^{\circ} \mathrm{C}$; EtOH, preserved in $95 \%$ ethanol), and life cycle stage are indicated.

fragment or with the internal primers. The sequences have been deposited in GenBank with accession Nos. AF177947-AF177976.

Sequence comparisons were made on $384 \mathrm{bp}$ at the $5^{\prime}$ end of the cytochrome $b$ gene, on the entire ND3 gene, and on the combined sequences (735 bp). Using the Molecular Evolutionary Genetics Analysis (MEGA) program (version 1.01) developed by Kumar et al. (1993), genetic distances were estimated with Kimura's (1980) two-parameter distances and phylogenetic relationships were inferred from the neighbour-joining (NJ) method; support of the data set for each branch point was tested by 500 bootstrap replications. For comparison, we also carried out the maximum parsimony procedure as implemented in MEGA (branch and bound method). Published cytochrome $b$ sequences from two European species, $L$. (L). planeri and L. (Le.) zanandreai (Tagliavini et al. 1994), were added to our data set, and the phylogenetic analyses above were repeated on the $267 \mathrm{bp}$ of sequence (positions 118-384) common to all 13 species.

\section{Results}

\section{Phylogenetic analysis}

The portion of the cytochrome $b$ gene sequenced had a 12-bp insert (positions 10-21) in lampreys relative to most teleosts (e.g., Cantatore et al. 1994), but there were no insertions or deletions among the lamprey species examined. The ND3 gene likewise showed no interspecific differences in length.

Intraspecific variation in the nucleotide sequence of both genes was relatively low in the current study. Cytochrome $b$ and ND3 sequences were identical in eight Pacific lampreys (L. tridentata) from British Columbia and Oregon, and four L. richardsoni, L. lethophaga, and L. hubbsi likewise showed no intraspecific differences, even among sites. Both gene sequences were identical in the landlocked sea lamprey of the current study and the anadromous sea lamprey from Lee and Kocher (1995). Intraspecific sequence differences were noted, however, in two species: $L$. aepyptera (cytochrome $b$ ) and L. similis (both genes) (Table 3). Lampetra similis from the Merced River in California varied consistently from the Oregon specimens by a total of two or three nucleotides, but the differences among the Oregon specimens (one or two nucleotides) were not population specific. All intraspecific nucleotide substitutions were thirdposition transitions.

Within the Lampetra genus, interspecific sequence variation ranged from 0 to $9.1 \%$ in cytochrome $b$ and from 0 to $12.5 \%$ in ND3 (Table 3). In both genes, there were no differences between $L$. ayresii and $L$. richardsoni and among L. tridentata, L. macrostoma, L. lethophaga, and L. similis from California. The greatest differences were observed between a haplotype of L. similis and L. appendix (cytochrome b) and L. similis and L. hubbsi (ND3). Comparisons between the Lampetra species and $P$. marinus showed variation between genera to range from 13.0 to $14.3 \%$ in cytochrome $b$ and from 16.0 to $17.4 \%$ in ND3.

The cytochrome $b$ and ND3 nucleotide sequences were used to estimate the phylogeny of the 11 Lampetra species using sea lamprey as an outgroup. Since the tree topologies obtained from each gene separately or together and those by the NJ or maximum parsimony method were almost consensus, just the phylogenetic analysis of the NJ method using the combined data is shown (Fig. 1). Only the topology of the NJ tree using the ND3 data differed slightly from Fig. 1 


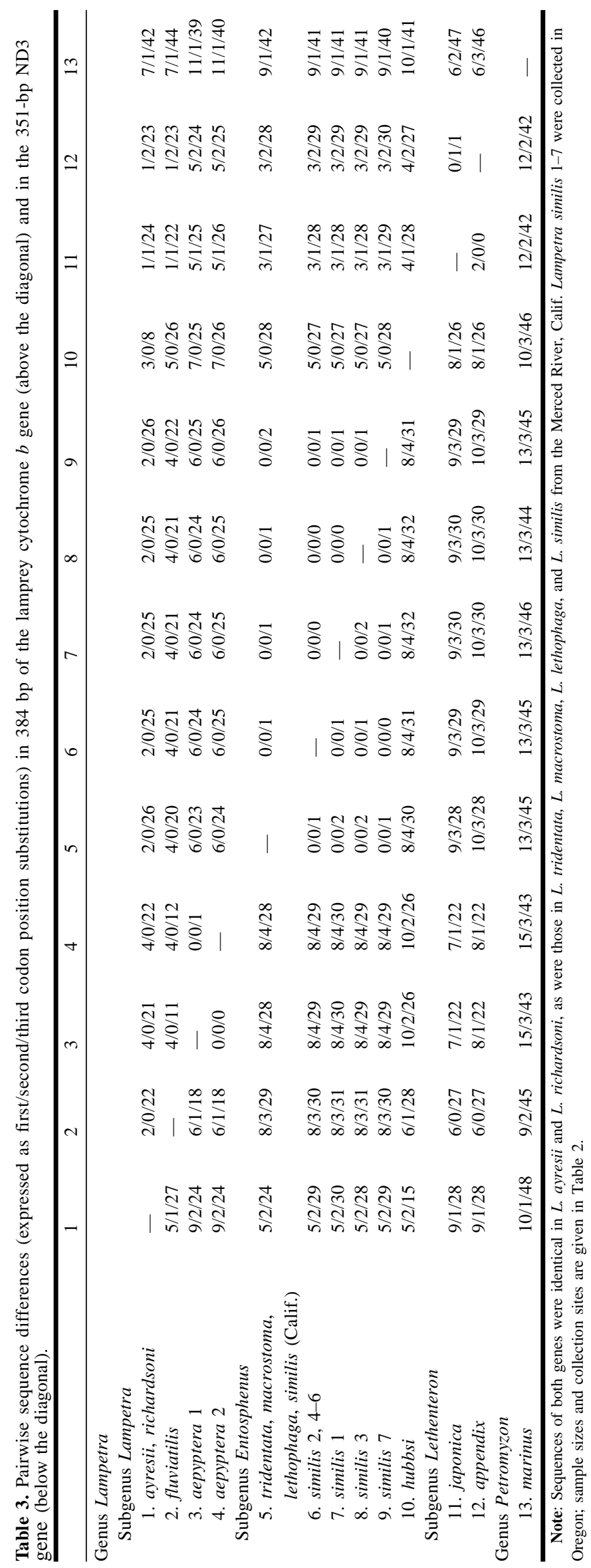

in that the L. ayresii and L. hubbsi clade clustered with the Entosphenus species rather than with the other Lampetra or Lethenteron species, but this difference was not reproducible at more than $50 \%$ bootstrapping. In all cases, four distinct clades were apparent: $(i)$ the Entosphenus subgenus without L. (E.) hubbsi, (ii) L. (E.) hubbsi with the westcoast North American $L$. (L.) ayresii and $L$. (L.) richardsoni, (iii) species of the Lampetra subgenus from Atlantic drainages, i.e., L. fluviatilis and L. aepyptera, and (iv) the Lethenteron species L. japonica and L. appendix.

A second consensus tree (not shown) was constructed to include $267 \mathrm{bp}$ of cytochrome $b$ sequence from $L$. (L.) planeri and $L$. (Le.) zanandreai from Italy (Tagliavini et al. 1994). Cytochrome $b$ sequence in L. planeri was identical to that of L. fluviatilis from Germany and the three European species grouped together; $L$. zanandreai did not form a clade with the other Lethenteron species. Lampetra aepyptera clustered with the three European species but with a lower bootstrap confidence limit $(57 \%)$ than it did with L. fluviatilis in Fig. 1 .

\section{Patterns of variation in cytochrome $b$ and ND3}

Overall nucleotide sequence variation among lamprey species was, on average, 1.35 times greater in the ND3 gene than in the cytochrome $b$ gene (Table 3 ). In both genes, third-position substitutions were more common than variations at first- and second-codon positions, and transition substitutions outnumbered transversions. The fraction of substitutions observed in first-, second-, and third-position sites was $13.8,2.6$, and $83.4 \%$, respectively, in cytochrome $b$ and $20.8,5.2$, and $74.1 \%$, respectively, in ND3. In cytochrome $b$, transitions accounted for $85.2 \%$ of all substitutions but only $77.1 \%$ of substitutions in ND3. Accordingly, the frequency of nonsilent nucleotide substitutions was two to three times higher in ND3 than in cytochrome $b$, and amino acid substitutions averaged $5.1 \%$ in ND3 but only $2.0 \%$ in cytochrome $b$. However, whereas the frequency of nonsilent substitutions for a given genetic distance was relatively constant among species pairs in ND3, this value was not uniform in cytochrome $b$ (Fig. 2). For example, despite a genetic distance between $L$. ayresii and $L$. tridentata nucleotide sequences of 0.079 , there were no amino acid differences. Similarly, there were only two amino acid differences between either $L$. ayresii or $L$. tridentata and P. marinus. In contrast, all pairwise comparisons with the relict nonparasitic species (L. aepyptera or L. hubbsi) showed comparatively high rates of nonsilent substitutions, and intermediate rates were observed in pairwise comparisons with $L$. appen$\operatorname{dix}$ (Fig. 2).

\section{Discussion}

\section{Relict species and subgenera}

Analysis of partial mitochrondrial DNA sequence permitted resolution of a number of questions concerning the phylogeny of the lamprey genus Lampetra. One of the clearest and most notable findings was that $L$. hubbsi, assigned to the genus Entosphenus by Vladykov and Kott (1976a) based largely on adult dentition (Table 1), appears more closely related to $L$. (L.) ayresii and $L$. ( $L$.) richardsoni than it is to any other Entosphenus species. On the strength of the mito- 
Fig. 1. Neighbour-joining analysis comparing species of the genus Lampetra using 735 bp of cytochrome $b$ and ND3 sequence; P. marinus is the outgroup. Numbers at nodes indicate bootstrap confidence levels; life history type is indicated: P, parasitic; NP, nonparasitic; A, anadromous; FW, freshwater. Collection data are provided in Table 2; locations in which more than one site was sampled are indicated by an asterisk.

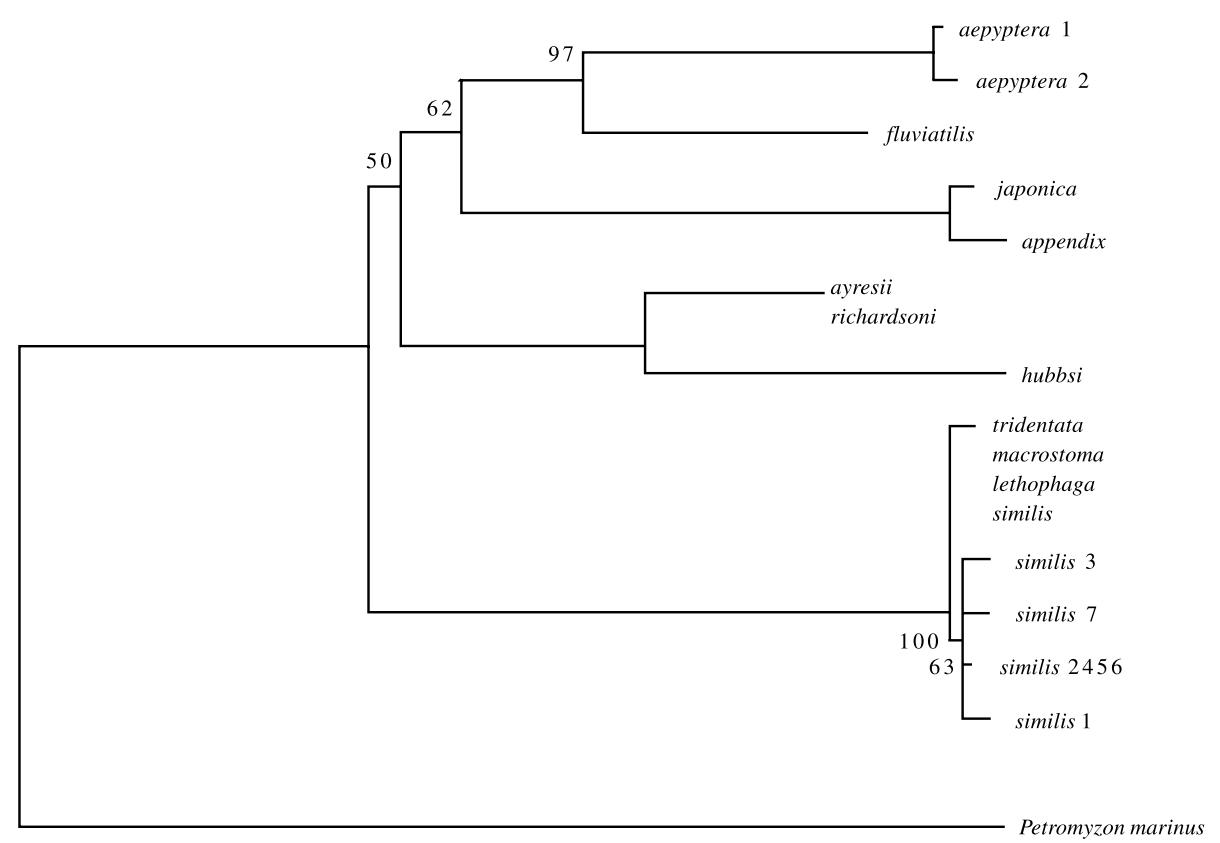

\begin{tabular}{lll} 
Subgenus & Type & Location \\
\cline { 3 - 3 } Lampetra & $\mathrm{NP}, \mathrm{FW}$ & Tennessee \\
Lampetra & $\mathrm{NP}, \mathrm{FW}$ & Tennessee \\
Lampetra & $\mathrm{P}, \mathrm{A}$ & Germany \\
Lethenteron & $\mathrm{P}, \mathrm{A}$ & Russia \\
Lethenteron & $\mathrm{NP}, \mathrm{FW}$ & Ontario \\
Lampetra & $\mathrm{P}, \mathrm{A}$ & $\mathrm{BC}$ \\
Lampetra & $\mathrm{NP}, \mathrm{FW}$ & $\mathrm{BC}$ \\
Entosphenus & $\mathrm{NP}, \mathrm{FW}$ & California* \\
Entosphenus & $\mathrm{P}, \mathrm{A}$ & $\mathrm{BC} *$ Oregon \\
Entosphenus & $\mathrm{P}, \mathrm{FW}$ & $\mathrm{BC}$ \\
Entosphenus & $\mathrm{NP}, \mathrm{FW}$ & California * \\
Entosphenus & $\mathrm{P}, \mathrm{FW}$ & California \\
Entosphenus & $\mathrm{P}, \mathrm{FW}$ & Oregon \\
Entosphenus & $\mathrm{P}, \mathrm{FW}$ & Oregon \\
Entosphenus & $\mathrm{P}, \mathrm{FW}$ & Oregon * \\
Entosphenus & $\mathrm{P}, \mathrm{FW}$ & Oregon \\
& & \\
& $\mathrm{P}, \mathrm{FW}$ & Ontario \\
& &
\end{tabular}

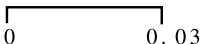

chondrial DNA data, it appears that L. hubbsi is a southern relict species of the $L$. ayresii lineage and should be placed in the subgenus Lampetra.

Also notable were the findings that two other relict species of the Lampetra genus, L. (Le.) zanandreai and L. (L.) aepyptera, both appear to have descended from the $L$. (L.) fluviatilis lineage. The molecular data show L. zanandreai to be more closely related to $L$. $(L$.) fluviatilis than to the two Lethenteron species and support its original designation as a species of Lampetra (Vladykov 1955). As was suggested by Vladykov and Kott (1979a), it appears that L. zanandreai descended from an L. fluviatilis-type ancestor, even though it is no longer sympatric with the present-day L. fluviatilis (Bianco 1986). Lampetra (L.) aepyptera likewise is no longer sympatric with any likely parasitic ancestor, and its phylogenetic position within the Lampetra genus has been the subject of considerable debate. Its morphological characteristics "are so poorly developed that they render its position and generic placement difficult and somewhat dubious" (Hubbs and Potter 1971), and at one time, it was placed in the "provisional and noncommittal" genus Okkelbergia (Hubbs and Potter 1971). Vladykov and Kott (1976b), however, concluded that this species displays no characteristics not found in Lampetra, and descent from either an L. ayresii-type ancestor (Vladykov and Kott 1979a) or an $L$. (Le.) japonica-type ancestor (Bailey 1980; Potter 1980) has been suggested, since both occur in North America. The mitochondrial DNA data are consistent with its present placement in the Lampetra subgenus as a nonparasitic species of considerable antiquity (Potter 1980) but suggest descent from an L. (L.) fluviatilis-type ancestor rather than from either North American species.

In addition to resolving these relationships within each of the Lampetra subgenera, the current molecular study has resolved some of the relationships among the subgenera. Potter (1980) grouped Entosphenus, Lethenteron, and Lampetra within a single genus largely due to the intergradation of characteristics found in $L$. hubbsi. Its bicuspid supraoral lamina and few velar tentacles are typical of Lampetra and Lethenteron, but its posterial circumorals and other features of its dentition (Table 1) resulted in its placement in Entosphenus (Vladykov and Kott $1976 a$ ). If L. hubbsi is removed from the Entosphenus taxon because of its closer genetic similarity to $L$. (L.) ayresii, however, the molecular data support the previous classifications which have held Entosphenus distinct from Lampetra and Lethenteron.

In contrast, the Lampetra and Lethenteron subgenera were not clearly delineated. Rather, the species assigned to these two taxa fell into three general groups and there was considerable overlap between the putative subgenera. The three groups were $(i)$ the westcoast North American Lampetra species (including L. (E.) hubbsi), (ii) Atlantic Lampetra species from both North America and Europe and L. (Le.) zanandreai, and (iii) the two other Lethenteron species examined in the current study. It was surprising that the North American and European species of the Lampetra subgenus had little more genetic affinity with one another than either did with the other subgenera, since $L$. ayresii and L. richardsoni, respectively, were once considered North American races of L. fluviatilis and L. planeri (Hubbs and 
Fig. 2. Frequency of nonsilent substitutions in the cytochrome $b$ and ND3 genes of lampreys versus genetic distance for 55 intra- and inter-specific pairwise comparisons. Solid circles represent all comparisons involving the relict nonparasitic species $L$. hubbsi and L. aepyptera, closed triangles represent the remaining comparisons involving the nonparasitic L. appendix, and open triangles represent all other species comparisons.
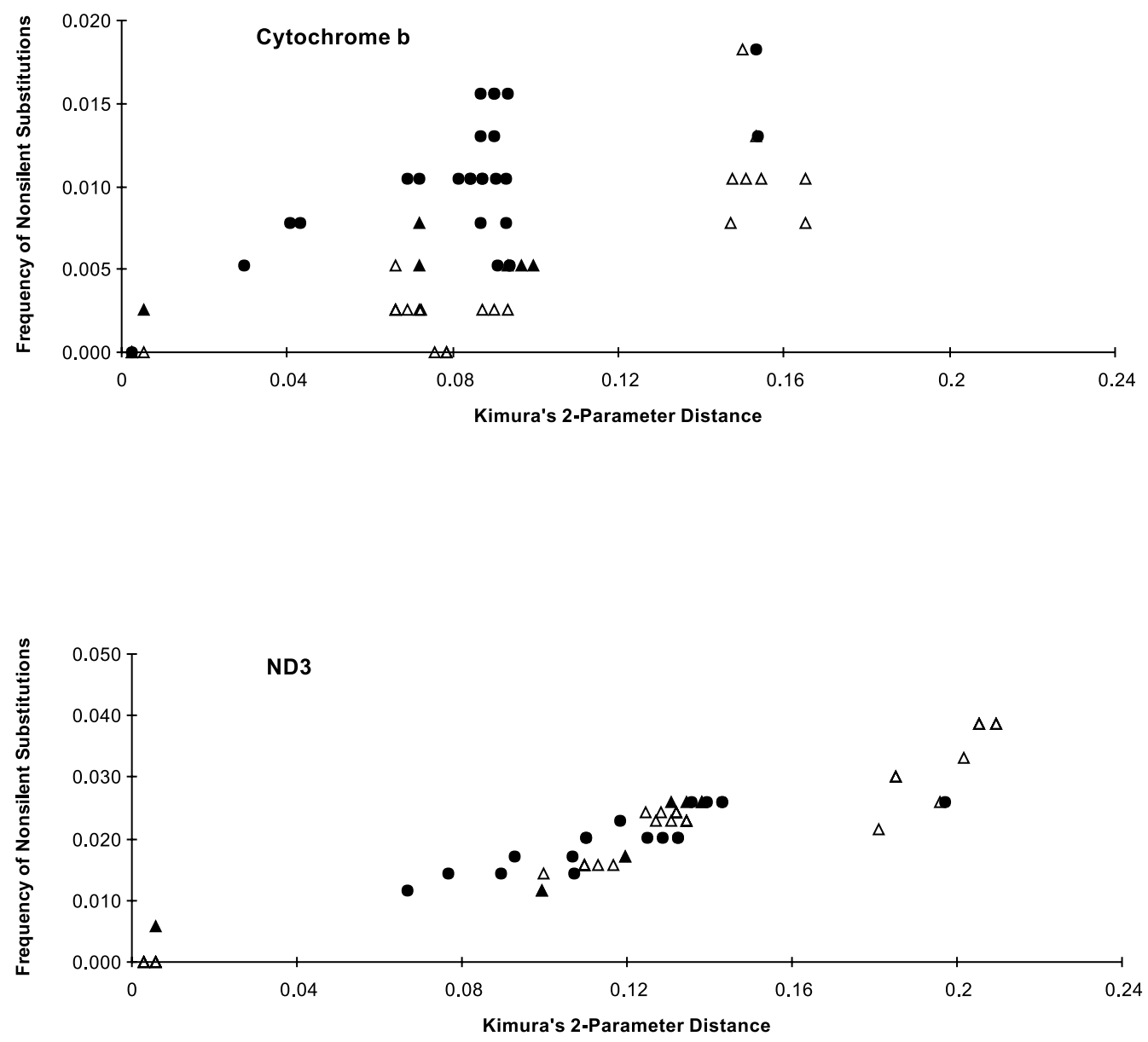

Potter 1971). The distinction between L. ayresii and L. fluviatilis was based on relatively small differences in body proportions (Table 1) whereas other morphological differences among other species seem not to be taxon distinctive. In particular, the presence of posterial circumorals does not seem to reflect a common evolutionary origin. As was discussed above, L. (E.) hubbsi is genetically most similar to L. (L.) ayresii despite the absence of posterials in the latter species. Posterials are present in most Lethenteron species, and like $L$. hubbsi, they are all unicuspid, but L. hubbsi did not cluster with these Lethenteron species. Likewise, $L$. zanandreai appears to be the only species with posterials in the L. fluviatilis lineage, and posterials may be absent in some L. zanandreai (Hubbs and Potter 1971; Bianco 1986). As was suggested by Bailey (1980), the presence of posterials appears to be inconsistent and unreliable in the separation of the subgenera, and given the substantial overlap between Lampetra and Lethenteron, morphologically and genetically, there appears to be little justification for the continued division. However, further clarification is needed; longer gene sequences are required from $L$. zanandreai, and more of the European and Asian representatives of the genus need to be examined. Similarly, complete resolution of the Lampetra-Lethenteron relationship will require examination of the Eudontomyzon and Tetrapleurodon genera. Bailey
(1980) included these two taxa from Eurasia and Mexico, respectively, in the Lampetra genus, and the subfamily classification of Vladykov and Kott (1979a) that groups Eudontomyzon with Lampetra and Lethenteron and Tetrapleurodon with Entosphenus also implies interrelatedness of these taxa with the three subgenera of Lampetra. Molecular data should go a long way toward resolving these taxonomic questions.

Assuming an overall rate of mitochondrial DNA sequence divergence of $2 \%$ per million years calculated for several mammalian species (Brown et al. 1979) and used to estimate divergence times in a variety of fish taxa (see review by Billington and Hebert 1991), the three relict species are estimated to have diverged from the L. fluviatilis or L. ayresii lineages about 0.9-2.7 million years ago. Divergences among the four major clades within the Lampetra genus occurred about 3-5 million years ago, and the Lampetra and Petromyzon genera diverged about 9-13 million years ago, maybe more if a general trend for slower substitution rates in many fishes and other ectotherms (see Billington and Hebert 1991) is also true for lampreys. In particular, suggestions of a slower rate of nonsilent substitutions in fishes relative to birds and mammals (Thomas and Beckenbach 1989) may be true of lampreys. For example, although 28 nucleotide differences were observed in the $384 \mathrm{bp}$ of cytochrome 
$b$ sequences from $L$. ayresii and $L$. tridentata, all were silent, and even relative to $P$. marinus, $L$. ayresii or $L$. tridentata cytochrome $b$ showed only two amino acid substitutions. It was interesting to note, however, that cytochrome $b$ amino acid sequences were less conserved in the relict species (Fig. 2). There were two amino acid differences between the closely related $L$. hubbsi and L. ayresii and three between L. aepyptera and L. fluviatilis. A similarly high rate of replacement substitutions in cytochrome $b$ was observed in L. zanandreai relative to L. planeri (Tagliavini et al. 1994) and suggests either a relaxation of certain functional constraints in these southerly nonparasitic lampreys or directional mutation. This same trend was not seen in the ND3 gene.

\section{Paired and satellite species}

In addition to addressing the ambiguous evolutionary relationships of some of the relict nonparasitic species, molecular analysis confirmed that the hypothesized paired species are closely related and diverged from one another more recently than the relict species diverged from their parasitic ancestors. For example, the molecular data agree with the present-day consensus of morphological studies that consider L. (Le.) appendix to be a derivative of L. (Le.) japonica. The paired nature of these two species, however, was not always considered obvious: the two species are no longer sympatric (McPhail and Lindsey 1970), and Zanandrea (1961) listed L. appendix as one of three nonparasitic species without a paired species. The molecular data are thus consistent with this hypothesis that $L$. appendix is part of the $L$. japonica assemblage yet more divergent from $L$. japonica than most of the other nonparasitic Lethenteron species (e.g., L. reissneri; Potter 1980). Applying the above rate of $2 \%$ sequence divergence per million years (Brown et al. 1979), L. japonica and L. appendix are estimated to have diverged about 270000 years ago. Furthermore, like the above relict species, L. appendix showed a relatively high rate of replacement substitutions relative to other species; of the four substitutions observed in both genes between L. japonica and L. appendix, three were nonsilent.

In contrast, the close genetic relationship between L. planeri and the parasitic L. fluviatilis was not surprising, since they have long been recognized as paired species (Hubbs and Potter 1971). Similarly, close relationships between $L$. richardsoni and $L$. ayresii and among $L$. tridentata and its presumed freshwater derivatives were expected from morphology-based taxonomies. Most members of paired and satellite species, in fact, were genetically indistinguishable from each other. Given the $735 \mathrm{bp}$ sequenced in the current study, this implies divergences within the past 70000 years. This rapid speciation is consistent with the distribution of these species and hypothesized changes in drainage patterns and river connections with glaciation. Lake Cowichan drainage patterns, for example, changed about 10000 years ago, resulting in isolation of the $L$. macrostoma lineage from searun L. tridentata in the Strait of Georgia (Beamish 1982). In rivers east of the Baltic, L. planeri is also believed to have originated within the last 10000 years (Hubbs and Potter 1971). To detect divergence times of 10000 years or less, however, it is estimated that more than 5000 bp of the mitochondrial genome would have to be sequenced, or perhaps a more variable region such as the control region (Lee et al. 1995) would be useful.

The lack of observed genetic divergence between members of paired and satellite species is not necessarily inconsistent with each being given species designation. Meyer et al. (1990) found a 363-bp fragment of cytochrome $b$ to be identical among seven species of Lake Victoria cichlids, and species designation cannot be decided on sequence differences alone, since rapid morphological differentiation resulting in distinct species may be decoupled from molecular divergence. Most lamprey taxonomies recognize life history type as a significant characteristic distinguishing between closely related species, and the different life history types appear to result in reproductive isolation. Although artificial hybridization between paired species has succeeded in producing viable larvae (e.g., Beamish and Neville 1992), interbreeding appears to be impaired by size differences between the life history types (Beamish and Neville 1992) and temporal and spatial differences in spawning (Beamish 1982).

Despite the lack of detectable differences among several species, intraspecific sequence differences were observed in L. aepyptera and L. similis. These were within the range found in other fish species (Billington and Hebert 1991), but the consistent genetic differences between populations of L. similis were notable. Although $L$. similis from the Merced River in California was genetically indistinguishable from L. tridentata, L. similis from the Klamath Basin of Oregon differed from them by two or three third-position transitions. This may indicate that the Merced River L. similis has arisen from $L$. tridentata more recently than the Oregon populations, and preliminary data suggesting that Merced River L. similis exhibits significant morphological and life history differences from the Oregon specimens (R.J. Beamish and J.H. Youson, unpublished data) support this hypothesis. Wide-ranging anadromous lampreys may have given rise to multiple freshwater parasitic or nonparasitic derivatives at different times, and the morphological differences observed among populations in other species (e.g., between $L$. pacifica and the now-synonymous $L$. richardsoni (Table 1), or L. folletti and L. lethophaga) may also reflect separate origins. More extensive molecular surveys will no doubt uncover more intraspecific differences and reveal the polyphyletic origins of a number of derived species.

In summary, mitochrondrial DNA sequence analysis answered several questions concerning the phylogeny of the lamprey genus Lampetra. Lampetra hubbsi, assigned to the genus Entosphenus largely on the basis of adult dentition, is most closely related to $L$. ayresii and should be placed in the subgenus Lampetra. Lampetra (Le.) zanandreai is genetically more similar to $L$. (L.) fluviatilis than to the other two Lethenteron species, and $L$. (L.). aepyptera is more closely related to $L$. ( $L$. ) fluviatilis than to the other North American species. Although there was no distinct division between the subgenera Lampetra and Lethenteron, Entosphenus (without $L$. hubbsi) formed a genetically separable taxon.

\section{Acknowledgements}

We thank F.W.H. Beamish, Department of Zoology, University of Guelph, Guelph, Ont., Y. Rosli, Pacific Institute of Fisheries and Oceanography, TINRO, Khabarovsk, Russia, and J.H. 
Trautner, Institute of Hydrobiology and Fisheries Science, University of Hamburg, Germany, for their kind donation of samples. We also thank T.D. Kocher, Department of Zoology, University of New Hampshire, Durham, N.H., for many insightful discussions. This study was supported by a Visiting Fellowship in a Canadian Government Laboratory (M.F.D.), the National Biotechnology Strategy (R.H.D.), Department of Fisheries and Oceans grants (R.H.D. and R.J.B.), and a Department of Fisheries and Oceans/Natural Sciences and Engineering Research Council of Canada Science Subvention grant (J.H.Y.).

\section{References}

Bailey, R.M. 1980. Comments on the classification and nomenclature of lampreys - an alternative view. Can. J. Fish. Aquat. Sci. 37: $1626-1629$.

Beamish, R.J. 1982. Lampetra macrostoma, a new species of freshwater parasitic lamprey from the west coast of Canada. Can. J. Fish. Aquat. Sci. 39: 736-747.

Beamish, R.J., and Neville, C-M.E. 1992. The importance of size as an isolating mechanism in lampreys. Copeia, 1992: 191-196.

Bianco, P.G. 1986. Lethenteron zanandreai (Vladykov, 1955). In The freshwater fishes of Europe. Vol. 1. Part I. Petromyzoniformes. Edited by J. Holčík. AULA-Verlag, Weisbaden. pp. 237-246.

Billington, N., and Hebert, P.D.N. 1991. Mitochondrial DNA diversity in fishes and its implications for introductions. Can. J. Fish. Aquat. Sci. 48(Suppl. 1): 80-94.

Brown, W.M., George, M., Jr., and Wilson, A.C. 1979. Rapid evolution of animal mitochondrial DNA. Proc. Natl. Acad. Sci. U.S.A. 76: 1967-1971.

Cantatore, P., Roberti, M., Pesole, G., Ludovico, A., Milella, F., Gadaleta, M.N., and Saccone, C. 1994. Evolutionary analysis of cytochrome $b$ sequences in some Perciformes: evidence for a slower rate of evolution than in mammals. J. Mol. Evol. 39: 589-597.

Hardisty, M.W. 1986. General introduction. In The freshwater fishes of Europe. Vol. 1. Part I. Petromyzoniformes. Edited by J. Holčík. AULA-Verlag, Weisbaden. pp. 19-83.

Hubbs, C.L. 1971. Lampetra (Entosphenus) lethophaga, new species, the nonparasitic derivative of the Pacific lamprey. Trans. San Diego Soc. Nat. Hist. 16: 125-164.

Hubbs, C.L., and Potter, I.C. 1971. Distribution, phylogeny and taxonomy. In The biology of lampreys. Vol. 1. Edited by M.W. Hardisty and I.C. Potter. Academic Press, London, U.K. pp. 1-65.

Janvier, P., and Lund, R. 1983. Hardistiella montanensis n. gen. et sp. (Petromyzontida) from the Lower Carboniferous of Montana, with remarks on the affinities of lampreys. J. Vertebr. Paleontol. 2: 407-413.

Kimura, M. 1980. A simple method for estimating evolutionary rate of base substitutions through comparative studies of nucleotide sequences. J. Mol. Evol. 16: 111-120.

Kumar, S., Tamura, K., and Nei, M. 1993. MEGA: Molecular Evolutionary Genetics Analysis, version 1.01. Pennsylvania State University Press, University Park, Pa.

Lee, W-J., and Kocher, T.D. 1995. Complete sequence of a sea lamprey (Petromyzon marinus) mitochondrial genome: early establishment of the vertebrate genome organization. Genetics, 139: 873-887.

Lee, W-J., Conroy, J., Howell, W.H., and Kocher, T.D. 1995. Structure and evolution of teleost mitochondrial control regions. J. Mol. Evol. 41: 54-66.
McPhail, J.D., and Lindsey, C.C. 1970. Freshwater fishes of northwestern Canada and Alaska. Bull. Fish. Res. Board Can. No. 173.

McVeigh, H.P., and Davidson, W.S. 1991. A salmonid phylogeny inferred from mitochondrial cytochrome $b$ gene sequences. J. Fish Biol. 39A: 277-282.

Meyer, A., Kocher, T.D., Basasibwaki, P., and Wilson, A.C. 1990. Monophyletic origin of Lake Victoria cichlid fishes suggested by mitochondrial DNA sequences. Nature (Lond.), 347: 550-553.

Palumbi, S.R. 1996. Nucleic acids II: the polymerase chain reaction. In Molecular systematics. 2nd ed. Edited by D.M. Hillis, C. Moritz, and B.K. Mable. Sinauer Associates, Inc., Sunderland, Mass. pp. 205-247.

Potter, I.C. 1980. The Petromyzoniformes with particular reference to paired species. Can. J. Fish. Aquat. Sci. 37: 1595-1615.

Richards, J.E., Beamish, R.J., and Beamish, F.W.H. 1982. Descriptions and keys for ammocoetes of lampreys from British Columbia, Canada. Can. J. Fish. Aquat. Sci. 39: 1484-1495.

Robins, C.R., Bailey, R.M., Bond, C.E., Brooker, J.R., Lachner, E.A., Lea, R.N., and Scott, W.B. 1980. A list of common and scientific names of fishes from the United States and Canada. Am. Fish. Soc. Spec. Publ. No. 12.

Robins, C.R., Bailey, R.M., Bond, C.E., Brooker, J.R., Lachner, E.A., Lea, R.N., and Scott, W.B. 1991. Common and scientific names of fishes from the United States and Canada. Am. Fish. Soc. Spec. Publ. No. 20.

Tagliavini, J., Tizzi, R., Conterio, F., Mariottini, P., and Gandolfi, G. 1994. Mitochondrial DNA sequences in three genera of Italian lampreys. Boll. Zool. 61: 331-333.

Thomas, W.K., and Beckenbach, A.T. 1989. Variation in salmonid mitochondrial DNA: evolutionary constraints and mechanisms of substitution. J. Mol. Evol. 29: 233-245.

Vladykov, V.D. 1955. Lampetra zanandreai, a new species of lamprey from northern Italy. Copeia, 1955: 215-223.

Vladykov, V.D. 1973. Lampetra pacifica, a new nonparasitic species of lamprey (Petromyzontidae) from Oregon and California. J. Fish. Res. Board Can. 30: 205-213.

Vladykov, V.D., and Follett, W.I. 1958. Redescription of Lampetra ayresii (Günther) of western North America, a species of lamprey (Petromyzonidae) distinct from Lampetra fluviatilis (Linnaeus) of Europe. J. Fish. Res. Board Can. 15: 47-77.

Vladykov, V.D., and Follett, W.I. 1965. Lampetra richardsoni, a new nonparasitic species of lamprey (Petromyzonidae) from western North America. J. Fish. Res. Board Can. 22: 139-158.

Vladykov, V.D., and Kott, E. 1976a. A new nonparasitic species of lamprey of the genus Entosphenus Gill, 1862 (Petromyzonidae) from south central California. Bull. South. Calif. Acad. Sci. 75: 60-67.

Vladykov, V.D., and Kott, E. 1976b. Is Okkelbergia Creaser and Hubbs, 1922 (Petromyzonidae) a distinct taxon? Can. J. Zool. 54: 421-425.

Vladykov, V.D., and Kott, E. 1976c. A second nonparasitic species of Entosphenus Gill, 1862 (Petromyzonidae) from Klamath River system, California. Can. J. Zool. 54: 974-989.

Vladykov, V.D., and Kott, E. 1979a. Satellite species among the holarctic lampreys (Petromyzonidae). Can. J. Zool. 57: 860-867.

Vladykov, V.D., and Kott, E. 1979b. A new parasitic species of the holarctic lamprey genus Entosphenus Gill, 1862 (Petromyzonidae) from Klamath River, in California and Oregon. Can. J. Zool. 57: 808-823.

Zanandrea, G. 1959. Speciation among lampreys. Nature (Lond.), 184: 380 .

Zanandrea, G. 1961. Studies on European lampreys. Evolution, 15: 523-534. 